\title{
Correction to: Community-Acquired Bacterial Pneumonia-Changing Epidemiology, Resistance Patterns, and Newer Antibiotics: Spotlight on Delafloxacin
}

\author{
Roopali Sharma ${ }^{1}$ (C) Christian E. Sandrock ${ }^{2} \cdot$ Joni Meehan $^{3} \cdot$ Nicolette Theriault $^{3}$
}

Published online: 28 January 2021

(c) The Author(s) 2021

\section{Correction to: \\ Clinical Drug Investigation (2020) 40:947-960 \\ https://doi.org/10.1007/s40261-020-00953-z}

The original version of this article unfortunately contained a few mistakes. The correct information is given below.

Page 951, column 2, part of the 1st paragraph, which previously read:

The OPTIC study [92] demonstrated omadacycline to be non-inferior to moxifloxacin but no benefit was observed in specific sub-groups such as COPD and asthma or diabetes, both of which are risk factors for poor outcomes. The safety of omadacycline was similar to older tetracyclines, with gastrointestinal events most frequently reported; nausea and vomiting were reported at incidences of $14.9 \%$ and $8.3 \%$, respectively. However, these events did not lead to discontinuation of therapy.

\section{Should read:}

The OPTIC study [92] demonstrated omadacycline to be non-inferior to moxifloxacin. Omadacycline was well tolerated with gastrointestinal events most frequently reported; nausea and vomiting were reported at incidences of $2.4 \%$ and $2.6 \%$, respectively.

Open Access This article is licensed under a Creative Commons Attribution-NonCommercial 4.0 International License, which permits any non-commercial use, sharing, adaptation, distribution and reproduction in any medium or format, as long as you give appropriate credit to the original author(s) and the source, provide a link to the Creative Commons licence, and indicate if changes were made. The images or other third party material in this article are included in the article's Creative Commons licence, unless indicated otherwise in a credit line to the material. If material is not included in the article's Creative Commons licence and your intended use is not permitted by statutory regulation or exceeds the permitted use, you will need to obtain permission directly from the copyright holder. To view a copy of this licence, visit http://creativecommons.org/licenses/by-nc/4.0/.
The original article can be found online at https://doi.org/10.1007/ s40261-020-00953-z.

Roopali Sharma

roopali.sharma@touro.edu

1 Department of Pharmacy Practice, Touro College of Pharmacy, 230 West 125th Street, New York, NY 10027, USA

2 University of California, Davis, Sacramento, CA, USA

3 GST Micro LLC, Henrico, VA, USA 